УДК: 621.793 .6

DOI: $10.31319 / 2519-8106.1(38) 2018.129042$

O.A. Beigyl, D.Sc., professor

D.B. Sereda, graduate student

Dniprovsk State Technical University, Kamianske

\title{
PHYSICO-CHEMICAL MODELING OF OBTAINING IN THE CONDITIONS OF SELF PROPAGATING HIGH-TEMPERATURE SYNTHESIS CORROSION RESISTANT COATINGS
}

The paper presents the results of the physical and chemical modeling of the production of doped chromium-plated coatings using the technology of self-spreading high-temperature synthesis on brass. A model was developed for the process of formation of doped chromium-lated in the conditions of thermal autoignition, which consists of 5 stages. Tests were conducted on the corrosion resistance of the obtained alloyed protective coatings. The conducted researches show that the SHS technology for obtaining doped chromium-plated coatings allows obtaining corrosion-resistant protective coatings with limited time of their formation.

Key words: modeling, corrosion resistance, synthesis, brass.

В роботі представлені результати фізико-хімічного моделювання отримання легованих хромоалітованних покриттів з використанням технології саморозповсюджувального високотемпературного синтезу, на латуні. Була розроблена модель процесу формування легованих хромоалітованних в умовах теплового самозаймання, яка складається з 5 стадій. Були проведені випробування по корозійної стійкості отриманих легованих захисних покриттів. Проведені дослідження показують, щи СВС технологія отримання легованих хромоалітованних покриттів дозволяє отримувати корозійно-стійкі захисні покриття при обмеженому часі їх формування.

Ключові слова: моделювання, корозійна стійкість, синтез, латунь.

There are many methods of strengthening the surface of brass and copper alloys, some of which are used in several versions. The most advanced techniques in this area include surface hardening using laser technology, electron beams, ion implantation, etc., as well as classical methods of chemical-thermal surface treatment (nitriding, boriding). Methods of obtaining protective coatings on metal products differ in coating technology, and the main purpose of the creation is good adhesion to the substrate, as well as obtaining a continuous, non-porous and resistant to this environment protective layer. Currently, the main methods of applying a protective coating are: galvanic precipitation during electrolysis, gas-thermal spraying or metallization, thermal diffusion saturation in powder, immersion in molten metal, cladding. By the type of joining the protective layer with the substrate, adhesive and diffusion metallic coatings are distinguished.

Surface saturation of copper materials with aluminum, chromium, boron, silicon, titanium and other elements is called diffusion saturation with metals. The product, the surface of which is enriched with these elements, acquires valuable properties, including high heat resistance, corrosion resistance, increased wear resistance and hardness.

In this regard, the actual application of technologies that allow to receive coatings with limited or minimal time of their formation. One of such technologies is the self-propagating high-temperature synthesis method [1-5].

Among the SHS processes involving chemical compounds as reagents, the most significant class (having the largest technological applications) are the so-called SHS reactions with a reducing stage.

The development of SHS as a research direction related to the synthesis of materials has supplemented the arsenal of combustion chemistry with new inorganic reactions, the range of which is continuously expanding. The main interest at the present time is represented by reactions in multicom- 
ponent systems conducted with the aim of obtaining complex single-phase compounds or heterogeneous materials with a given ratio of phase components [6-8].

The thermodynamic calculations that help to calculate the adiabatic temperature and the equilibrium composition of the combustion products from the known thermodynamic properties of substances are of great help in the search for reactions of technological combustion. Based on these data, it is estimated whether it is expedient to implement chemical interaction in the combustion regime in certain systems.

Brasses have good corrosion resistance in the ordinary atmosphere, as well as in the marine climate. In this case, brass containing less than $15 \% \mathrm{Zn}$, for corrosion resistance are close to copper.

The corrosion rate of brass in atmospheric conditions does not exceed $0.001 \mathrm{~mm} /$ year; in fresh water the rate of corrosion is insignificant and at a temperature of $20^{\circ} \mathrm{C}$ is $0.0025 \ldots 0.025 \mathrm{~mm} /$ year.

Brass intensively corroded under the influence of mineral acids (nitric, hydrochloric). Sulfuric acid acts much more slowly on latva, but in the presence of oxidizing agents $\left(\mathrm{K}_{2} \mathrm{Cr}_{2} \mathrm{O}_{7}, \mathrm{Fe}_{2}\left(\mathrm{SO}_{4}\right)_{3}\right\}$, the rate of corrosion increases by two orders of magnitude. Brasses are very stable in solutions of alkalis (with the exception of ammonia) and in concentrated solutions of neutral salts.

Strong corrosive effect on brass has hydrogen sulphide. In this case, brass with an increased content of zinc (over 30\%) is more stable in the hydrogen sulphide environment than brass with a low content of zinc.

For the correct choice of synthesis conditions, the results of studies of the kinetics of SHS reactions, determination of kinetic constants, activation energies are useful.

The process of obtaining chromoaluminosilated coatings in the regime of thermal autoignition is considered. Studies were carried out on samples of brass LC40MC3J.

As the gas-transport agent (GTA), crystalline iodine $\left(\mathrm{J}_{2}\right)$ and ammonium chloride $\left(\mathrm{NH}_{4} \mathrm{Cl}\right)$ were used. To carry out joint saturation of the surface with chromium, aluminum and silicon, the content of crystalline silicon was chosen within the range of up to $7 \%$ by weight, and the siliceous component was chosen up to $20 \%$. The concentration of GTA in the charge was 1 and $2 \%$ by mass, respectively.

The protective layers were applied in a pilot plant including the following functional systems: reaction equipment, gas supply system and a system for monitoring and regulating technological parameters [9-11].

As a result of physicochemical modeling, the process of forming coatings can be conditionally divided into the following stages (Figure 1):

I - inert heating of the reaction mixture to the ignition temperature;

II - the stage of thermal autoignition (the interaction of $\mathrm{Cr}_{2} \mathrm{O}_{3}$ and $\mathrm{Al}$ ). The temperature in the reactor rises to a maximum, gaseous compounds are formed, and the diffusing elements are transported to the surface of the substrate;

III - the stage of heating the product. The temperature of the reaction mixture is reduced to the temperature of isothermal aging, the saturating elements diffuse into the substrate;

$\underline{\text { IV }}$ - isothermal aging, during which the diffusion growth of the coating takes place;

$\underline{\mathrm{V}}$ is the cooling stage. The formation of the siliconized layer occurs with a lower intensity due to a decrease in the diffusion coefficient of silicon with decreasing temperature.

For corrosion resistance studies, corrosion media simulating the intended application areas were used:

- pumps for pumping acids in the production of titanium;

- bearing assemblies at the objects of special equipment in the rocket and space and defense industries;

- for the manufacture of simple configuration parts for critical purposes and fittings for marine shipbuilding, operating at temperatures up to $300{ }^{\circ} \mathrm{C}$; massive parts, propellers and their blades for the tropics. 


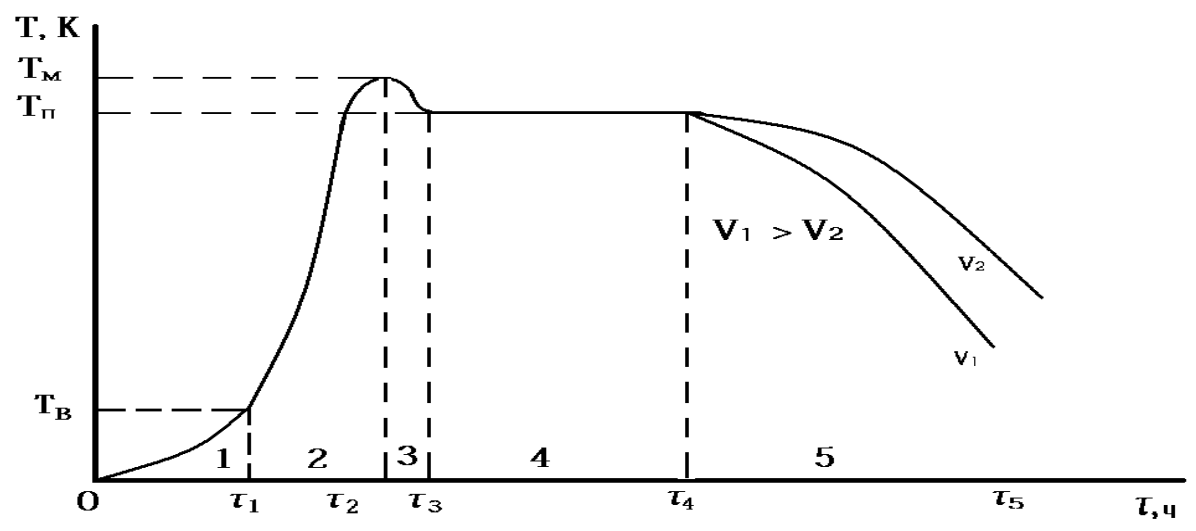

\begin{tabular}{|c|c|c|c|c|}
\hline 1 Stage & 2 Stage & 3 Stage & 4 Stage & 5 Stage \\
\hline $\begin{array}{l}\mathrm{T} \uparrow \\
\mathrm{NH} 3, \mathrm{HCl}, \mathrm{HF}, \\
2 \mathrm{~J}\end{array}$ & $\begin{array}{l}\mathrm{T} \uparrow \frac{d c}{D x} \downarrow, \\
\mathrm{CrCl}, \mathrm{CrCl}_{2}, \mathrm{AlCl}, \\
\mathrm{AlCl}_{2}, \mathrm{CrF}, \mathrm{CrF}_{2}, \\
\mathrm{CrF}_{4} \\
\mathrm{AlI}, \mathrm{AlI} 2, \mathrm{All} 3, \\
\mathrm{BF} 3, \mathrm{TiCl} 2, \mathrm{TiCl}_{3} \\
\mathrm{SiCl}, \mathrm{SiCl} 2, \mathrm{TiF}_{3}, \\
\mathrm{CuI}, \mathrm{CuI} 2\end{array}$ & $\begin{array}{l}\mathrm{T}_{\Pi} \downarrow \frac{d c}{D x} \downarrow, \\
\alpha \text { - solid solution } \\
\mathrm{Cr}, \mathrm{Al}, \mathrm{Si}, \mathrm{B}, \mathrm{Ti}\end{array}$ & $\begin{array}{l}\mathrm{T}_{\mathrm{n}}=\text { const. } \mathrm{CuSi}, \\
\mathrm{CuAl}, \mathrm{CuAl}_{2}, \\
\mathrm{CuTi} \mathrm{Ti}_{2} \mathrm{Cu}_{3}, \\
\mathrm{Cu}_{3} \mathrm{Al}, \mathrm{Al}_{3} \mathrm{Si} \\
\mathrm{CuB}, \mathrm{CuZn}_{2} \\
\mathrm{Cu}_{5} \mathrm{Si}_{4}, \mathrm{Cu}_{5} \mathrm{Si}\end{array}$ & $\begin{array}{l}\frac{d c}{D x} \downarrow, \mathrm{T}_{\Pi} \downarrow \\
\mathrm{CuSi}, \mathrm{CuAl} \\
\mathrm{CuAl}{ }_{2}, \mathrm{CuTi}, \mathrm{CuTi} \\
2, \\
\mathrm{Cu}_{3} \mathrm{Al}, \mathrm{Al}_{3} \mathrm{Si} \\
\mathrm{CuB}, \mathrm{CuZn}_{2} \\
\mathrm{Cu}_{5} \mathrm{Si}_{4}, \mathrm{Cu}_{5} \mathrm{Si}\end{array}$ \\
\hline
\end{tabular}

Fig. 1. The scheme for the formation of doped chromium-plated protective coatings on brass LC40MC3J, obtained in the regime of thermal self-ignition of SHS-charge, $t_{\mathrm{M}}=900^{\circ} \mathrm{C}, t_{\mathrm{m}}=700-800^{\circ} \mathrm{C}$

To increase the corrosion resistance of brass LC40MC3J it is necessary to saturate the protective layer with elements that will form passive films. In our case, when the ion passivation potential is reached, oxide films of the composition: $\mathrm{Cr}_{2} \mathrm{O}_{3}, \mathrm{Al}_{2} \mathrm{O}_{3}, \mathrm{TiO}_{2}, \mathrm{SiO}_{2}$, are formed, which protect the metal from destruction.

The choice of corrosive media was carried out based on the expected areas of operation of brass (for parts operating in corrosive acid media). The results of corrosion tests for mass loss, for 7 days, are shown in Fig. 2.

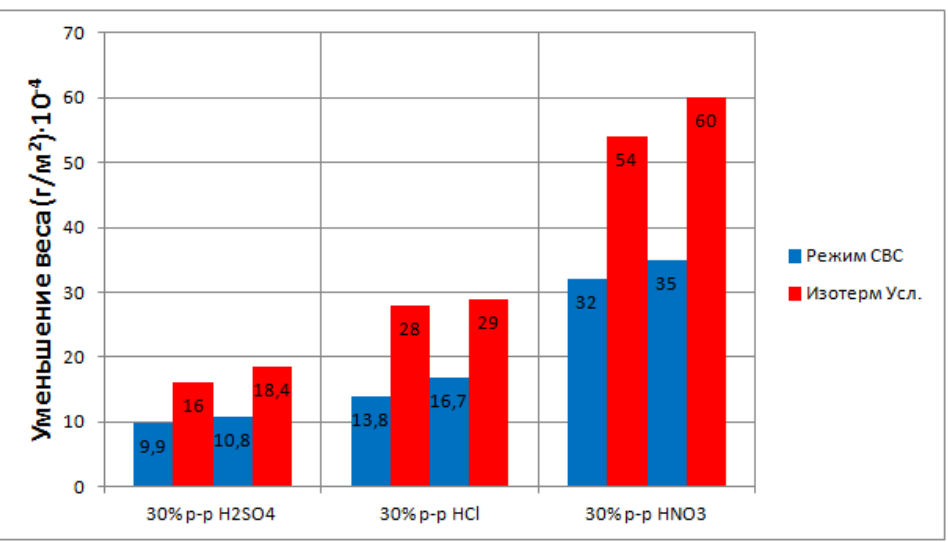

Fig. 2. Comparative diagram of the corrosion resistance of protective coatings obtained under SHS and isothermal conditions. (Construction material - brass LC40MC3J) at $t_{\mathrm{n}}=800{ }^{\circ} \mathrm{C}, \tau_{\mathrm{B}}=60 \mathrm{~min}$

When tested in a $30 \%$ aqueous solution of hydrochloric acid, protective coatings doped with silicon and titanium showed better resistance, having weight loss 13,8 and $16,7 \mathrm{~g} / \mathrm{m}^{2}$. Metallographic analysis showed that the coatings on all samples were uniformly corroded to a shallow depth, therefore, in order to work in a $30 \%$ aqueous solution of hydrochloric acid, it is advisable to use protective 
coatings doped with silicon, which in addition to good corrosion resistance also have high wear resistance. When tested in a $30 \%$ aqueous solution of nitric acid, a good resistance was shown by protective coatings doped with titanium and silicon, having correspondingly weight loss 32 and $35 \mathrm{~g} / \mathrm{m}^{2}$.

When tested in a $30 \%$ aqueous solution of sulfuric acid, all protective coatings have good resistance. Thus, when silicon is doped with $10.8 \mathrm{~g} / \mathrm{m}^{2}$ and doped with titanium, $9,9 \mathrm{~g} / \mathrm{m}^{2}$. A comparative analysis of the corrosion resistance of protective coatings obtained under isothermal conditions showed that they have a weight loss of $1,7-2,1$ times greater.

The results obtained can be explained by the formation of doped phases on the surface, leading to passivation of the surface in aggressive media. It is established that mechanical stresses affect the corrosive behavior of metals, due to the receipt of additional energy by the structural material, because the level of residual stresses in coatings obtained under conditions of thermal self-ignition of SHScharge is higher.

\section{Conclusions}

As a result of physical and chemical modeling, a model was developed for the formation of doped chromium-plated coatings under conditions of thermal autoignition, which consists of 5 stages. Anticorrosive protective coatings have been obtained to improve the performance characteristics of machine parts and mechanisms. It is proved that, after the test, the best parameters have protective coatings doped with silicon and titanium, due to the formation of passive oxide films $\mathrm{Al} 2 \mathrm{O} 3, \mathrm{Cr} 2 \mathrm{O} 3$, $\mathrm{TiO} 2, \mathrm{SiO} 2$. A comparative analysis of the corrosion resistance of protective coatings obtained under isothermal conditions and SHS showed that they have a mass loss of 1.7-2.1 times higher.

\section{List of reference links}

1. Мержанов А.Г., Юхвид В.И., Боровинская И.П. Самораспространяющийся высокотемпературный синтез литых тугоплавких неорганических соединений. Докл. АН СССР, 1980, т. 255, № 1, с. 120-124.

2. Мержанов А.Г. Процессы горения и синтез материалов /Под ред. В.Т. Телепы, А.В. Хачояна. Черноголовка: ИСМАН, 1998. 512 c.

3. Середа Б.П., Скачков В.О., Іванов В.І., Усенко Ю.І. Хромування сталей методом газотранспортних СВС-реакцій //Металознавство та обробка металів. - 1999. - № 4. с. 25-27.

4. Merzhanov A.G., Yukhvid V.I. The self-propagating high-temperature synthesis in the field centrifugal forces. In:Proc. Of the First US-Japan. Workshop on Combust. Synth., Jan.11-12, 1990. Tokyo: Nat. Res. Inst. Metals Publ., 1990, p. 1-21.

5. Коган Я.Д., Середа Б.П., Штессель Э.А. Высокоинтенсивный способ получения покрытий в условиях СВС//Металловедение и термическая обработка металлов. - 1991.-№6.-c.39-40.

6. Середа Б.П., Кругляк И.В. Моделирование процессов хромирования и силицирования в условиях самораспространяющегося высокотемпературного синтеза //Металловедение и термическая обработка металлов. - 2002, № 4 - с. 29-33

7. Середа Д.Б. Получение хромоалитированных покрытий на углеродистых материалах в условиях самораспрастраняющегося высокотемпературного синтеза / Середа Б.П., Середа Д.Б.., Белоконь Ю.А., Кругляк И.В. // Строительство, материаловедение, машиностроение: Сб. науч. трудов. Вып. 80 - Дн-вск.,ГВУЗ ПГАСА, 2015. - 380 с., С. 296-301.

8. Кругляк И.В. Получение многокомпонентных силицированных покрытий в режиме горения СВС-систем / Кругляк И.В., Середа Д.Б., Кругляк Д.О.// Сб. научных работ «Перспективные технологии и приборы» Луцк: Луцкий НТУ, 2017. - № 10(1). - С. 89-98.

9. Sereda B., Sereda D. Advanced Chromoaluminizing Coatings for Wear and Heat-resistance on Composite Materials under SHS. Material science and technology- 2015.. Columbus, OH,USA.1821 p., P. 229-232.

10.Sereda B., Sereda D. Aluminized Multifunctional Coating on Steel in SHS Condition. Material science and technology -2014. Pittsburgh. Pennsylvania USA. 2224 p. P. 482-486.

11. Sereda D. The Researching of Deformational Parameters at Copper Alloys Rolling with Protective Coatings / Sereda D., Sereda B., Kruglyak I., Kruglyak D., Sheyko S. // Material science and technology -2011.. Columbus, Ohio USA. 2011. - P. 1710-1714. 